\title{
Trailer Vendor Selection with Fuzzy-Quality Function Deployment (Fuzzy-QFD) Approach and Goal Pro- gramming (Case Study: Krakatau Argo Logistics Inc.)
}

\author{
Asep Ridwan ${ }^{1 *}$, Ade Irman ${ }^{1}$, Ahmad Aji Abadi ${ }^{1}$, Didi Suhendi ${ }^{2}$, Fatah Sulaiman ${ }^{3}$ \\ ${ }^{1}$ Department of Industrial Engineering Faculty of Engineering University of Sultan Ageng Tirtayasa, Indonesia \\ ${ }^{2}$ Department of Industrial Engineering Krakatau Argo Logistics Inc. Banten, Indonesia \\ ${ }^{3}$ Department of Chemical Engineering Faculty of Engineering University of Sultan Ageng Tirtayasa, Indonesia \\ ${ }^{*}$ Corresponding author. Email: asep.ridwan@ untirta.ac.id
}

\begin{abstract}
Krakatau Argo Logistics Inc. (KAL Inc.) is a company that works in the field of multimodal transportation business services. Currently, the selection of KAL Inc. trailer vendors is only based on the availability and intuition of decisionmakers. Therefore, it is necessary to do research this trailer vendor selection using the fuzzy-quality function deployment (fuzzy-QFD) approach and goal programming. The results obtained from the fuzzy-QFD method are the scores and rankings of each existing trailer vendor. For GPG Inc. is ranked 1 with a score of 471.21, JS Inc. is ranked 2nd with a score of 451.91, LAA Inc. is ranked 3rd with a score of 424.12, KSK Inc. is ranked 4th with a score of 395.9, ISLC Inc. is ranked 5th with a score of 391.33, SBW Inc. is in 6th place with a score of 385.95, and PSJ Inc. is ranked 7 th with a score of 361.24. After obtaining a score for each vendor, a programming objective is calculated to determine which trailer vendor is used for a project. LAA Inc. of 2000 tons, ISLC Inc. of 1000 tons, JS Inc.of 4000 tons, KSK Inc. of 2000 tons, and GPG Inc. 4000 tons.
\end{abstract}

Keywords: Fuzzy-QFD, Vendor Selection, Goal Programming, Quality Function Deployment

\section{INTRODUCTION}

Transportation has a great influence on logistics performance because it is the most important resource in the distribution system. Transportation acts as a center for operational activities starting from sending raw materials from suppliers to the place of production, moving inventory to other factories or distribution centers, and distributing products to consumers. Transportation makes a big contribution to the company's overall operational costs, so companies must choose the right transportation [1].

The transportation segment is the largest contributor to logistics costs, followed by freight forwarding and warehousing. Logistics costs are an important factor used in the selection of Third Party Logistics (3PL). The use of Third Party Logistics (3PL) so far has reduced the company's logistics costs, so that many companies use Third Party Logistics services [2].

Krakatau Argo Logistics Inc. (KAL Inc.) is a company that works in the field of multimodal transportation business services that serve land, sea and air transportation. KAL Inc. as a third party logistics service provider is committed to working with several customers to be responsible for handling stevedoring, warehousing, distribution and other activities. For the needs of the transport fleet to meet the demands of its customers, KAL Inc. also outsources vendors to several transporter services. The vendor selection process is one of the important activities and needs to be considered because the vendor used will affect the company's operational costs and customer satisfaction which is related to company performance. Vendor selection is also an important activity because it is related to the company's goal to be able to make quality products or services [3]. Therefore, vendor selection activities must be carried out as well as possible in an effort to provide good service in order to create customer satisfaction and maintain the quality of the company itself.

In shipping activities using trailers, KAL Inc. evaluates and selects trailer vendors for each delivery project received from customers. Currently the selection of KAL 
Inc. trailer vendors is only based on availability and intuition of decision makers. The evaluation of the trailer vendor assessment that is currently being carried out at KAL Inc. is also still based on the same general parameters as other supplier assessments, so the results of the trailer vendor selection and evaluation are still not optimal. This non-optimality causes several problems such as costs that exceed the set budget, and time delays when the service is carried out by the trailer vendor used. According to Naafitarama (2019) [2], the selection of the wrong trucking vendor will disrupt the expedition's operational activities. Mistakes in vendor selection can cause losses to the company [4]. Therefore, this research was conducted with the aim of creating a special trailer vendor selection model for distribution activities at KAL Inc. as an effort to improve the quality of company services. Vendor selection will be carried out using a systematic approach model. The method used in this research is the method of Fuzzy-Quality Function Deployment (FuzzyQFD) and Goal Programming (GP). Fuzzy-QFD is used to provide scores and rankings for trailer vendors available at KAL Inc. The use of the Fuzzy QFD method has proven to be effective in quality to be quantitative [5]. In the QFD method, the correlation between customer requirements and design requirements is obtained in qualitative data, therefore, fuzzy logic is considered more effective than ordinary numerical scales. The GP method is used to determine trailer vendors and their allocation for one KAL Inc. transportation project. Multi Objective (Goal) Programming is very suitable for multi-purpose problems because it is through the deviation variable. This method automatically captures information about the relative achievement of existing goals. Therefore, the given optimal solution can be limited to a feasible solution that incorporates the desired performance measures [6].

\section{METHODS}

This research was conducted at KAL Inc. In this study, the selection of trailer vendors was carried out based on the criteria needed by the company and the limitations that existed in a case study of shipping goods with a trailer vendor. The data collection process was carried out by brainstorming and filling out questionnaires with experts in their fields at KAL Inc., namely the President Director, Procurement Department, and Logistics Service Department. In addition, researchers also collect secondary data obtained from company data. The method used in this research is the fuzzy-QFD method and goal programming (GP). The research design for the selection of trailer vendors this time can be seen in Fig.1.
Trailer vendor selection begins with the identification of available vendors and evaluation or characteristics of these vendors. Furthermore, qualitative analysis was carried out using the fuzzy-QFD method. A fuzzyQFD method is used to score and rank the available trailer vendors. This method will identify the company's needs and relevant criteria for the trailer vendor assessment by making a House of Quality (HOQ). The process of making HOQ will use fuzzy logic. Identification and assessment will be carried out by experts at KAL Inc., including the President Director, Head of Procurement, and Head of the Logistics Service Department. Then the weight value of each criterion generated from the HOQ is correlated with each available trailer vendor to determine the weighting and ranking of each available vendor. The score and weighting of the qualitative analysis will be input to the quantitative analysis carried out using goal programming. From the goal programming calculations, vendor decisions will be made and their allocations will be used in a case study of a delivery project using a trailer vendor. In this method, decision variables, objective functions, and constraints will be made according to the company's conditions. Completion of this GP method is done with the help of LINGO software.

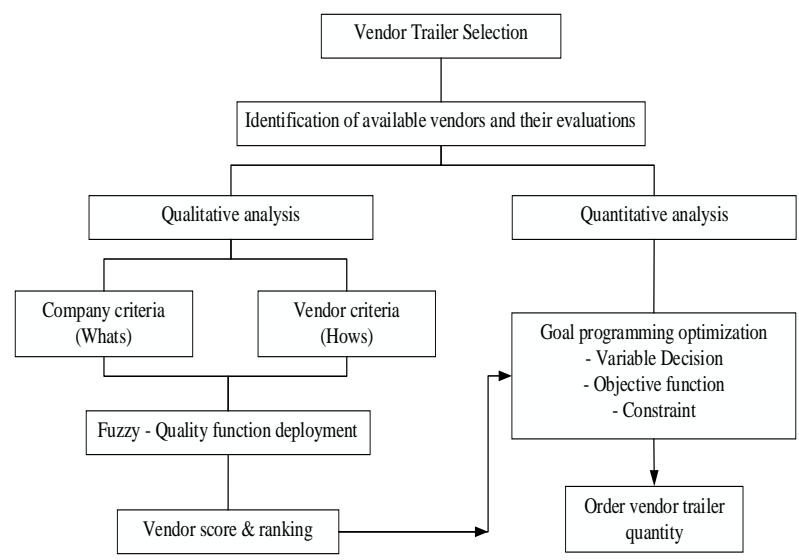

Figure 1. Research Design

\subsection{Fuzzy-Quality Function Deployment}

Quality Function Deployment (QFD) is a method used to incorporate customer requests into a company policy for product/service development. QFD calculations produce attributes or criteria desired by consumers, which then the company will respond to the wishes of these consumers through policies made or improvements made in the production process / services [7]. QFD is a method for maximizing customer requirements (WHATs) which is embodied in design requirements (HOWs) whose mechanism is to create a House of Quality (HOQ) [5]. Fuzzy-Quality Function Deployment is a 
method to strengthen the results of QFD calculations, because to clarify the obscuration of consumer judgments [7].

The following are the steps for selecting a FuzzyQFD supplier [8]:

a. Identification of Vendor Characteristics Required by Companies (WHATs)

b. Identification of Criteria Relevant to Vendor Assessments (HOWs)

c. Determining the relative importance of "WHATs". At this stage, the assessment of the level of importance is carried out using linguistic variables. Then the linguistic variable is translated into a triangular fuzzy number.

d. Determine the correlation score "WHATs " - "HOWs " and create HOQ. At this stage the correlation assessment is also carried out using linguistic variables. Then the linguistic variable is translated into a triangular fuzzy number.

e. Determine the weight of "HOWs ".

f. Create a correlation matrix between "HOWs"

g. Determine the impact of each potential supplier on the attributes considered (HOWs).

h. Compile the final ranking based on FSI (Fuzzy Suitability Index). At this stage, FSI calculations will be carried out to then score each supplier to determine the ranking of that supplier.

\subsection{Goal Programming}

Goal programming is one of the mathematical methods of extension of the linear programming method which can be used as a basis for decision making to analyze and find an optimal solution to a problem, where this method involves many objectives to obtain the optimal solution. [9].

There are several steps that must be taken in the formulation of the goal programming problem, namely [10]:

a. Determination of decision variables.

b. Determination of the objective function.

There are 3 kinds of possible relationships, namely:

$$
f_{i}\left(x_{i}\right)=b_{i}, f_{i}\left(x_{i}\right) \geq b_{i} \text {, and or } f_{i}\left(x_{i}\right) \leq b_{i}
$$

c. Formulation of target function.

In this step, each objective on the left side is added with the deviation variable

$$
f i(x)+d i^{-}-d i^{+}=b i
$$

d. Goal programming model completion.

The general form of the GP method is: Minimize

$$
\mathrm{Z}=\sum_{\mathbf{i}=\mathbf{1}}^{\mathbf{n}}\left(d_{i}^{+}+d_{i}^{-}\right)
$$

Constraint:

$$
\begin{gathered}
\sum_{i=1}^{n} a_{i j X_{j}-d_{i}^{+}+d_{i}^{-}=\mathrm{b}_{i}} \\
j=1,2, \ldots, \mathrm{m} \\
k=1,2, \ldots, \mathrm{p} \\
\mathrm{M}, \mathrm{n}, \mathrm{p} \in Z^{+}
\end{gathered}
$$

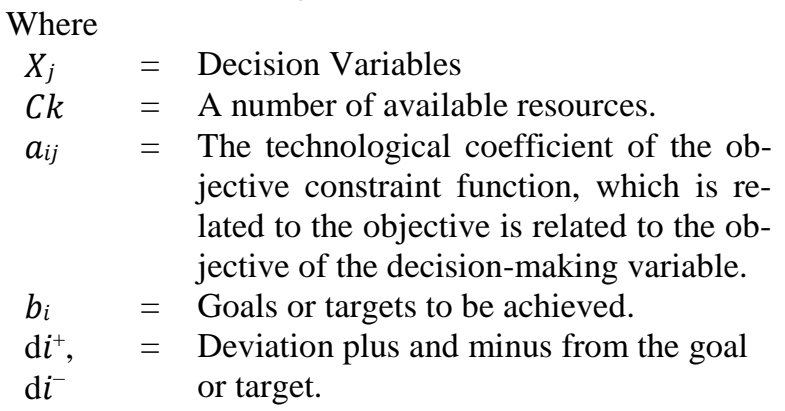

In determining the formulation of the goal programming method, the formulas used are composed of objective functions, decision variables, and problem constraints.

\section{RESULTS AND DISCUSSION}

The method used in this research is the fuzzy-QFD method and goal programming. The fuzzy-QFD method will be carried out first to determine the available trailer vendor scores, and then proceed with the goal programming method to determine which vendors will be used in a case study of a delivery project at KAL Inc.

\subsection{Fuzzy-QFD}

The Fuzzy-QFD method will be carried out with the following steps:

\subsubsection{Identification of Trailer Vendor Character- istics Required by Companies (WHATs)}

Identification of the trailer vendor characteristics needed by the company was carried out by brainstorming with experts, including the Procurement Division Manager, Logistics Service Manager, and the President Director of KAL Inc.. Brainstorming is done by discussing and using some of the existing literature. From the results of the brainstorming, several "WHATs" needs are obtained which are expected to be found in trailer vendors, including:

a. Availability in order fulfillment

b. Flexibility of response to requests

c. Cost

d. Occupational health and environmental safety

e. Unit is worth using

f. On time delivery

g. Experience

h. Information coordination

i. Operation control 


\subsubsection{Identification of Criteria Relevant to} Trailer Vendor Assessments (HOWs)

Identification of Trailer Vendor Characteristics needed by the company is also done by brainstorming with experts. Table 1 is a table of trailer vendor assessment criteria from the brainstorming results.

Table 1. Trailer Vendor Assessment Criteria (HOWs)

\begin{tabular}{|c|c|c|c|}
\hline $\begin{array}{c}\text { Company Needs } \\
\quad(\text { WHATs })\end{array}$ & $\begin{array}{c}\text { Assessment } \\
\text { Criteria } \\
\text { (HOWs) }\end{array}$ & $\begin{array}{l}\text { Code of } \\
\text { HOWs }\end{array}$ & Ref \\
\hline $\begin{array}{l}\text { Availability in or- } \\
\text { der fulfillment }\end{array}$ & \multirow[t]{2}{*}{ Availability } & \multirow[t]{2}{*}{ B1 } & \multirow[t]{2}{*}{ [3] } \\
\hline $\begin{array}{l}\text { Flexibility of re- } \\
\text { sponse to re- } \\
\text { quests }\end{array}$ & & & \\
\hline Cost & Cost & B2 & [11] \\
\hline $\begin{array}{l}\text { Occupational } \\
\text { health and envi- } \\
\text { ronmental safety }\end{array}$ & \multirow[t]{2}{*}{ Feasibility } & \multirow[t]{2}{*}{ B3 } & \multirow[t]{2}{*}{ [11] } \\
\hline Unit is worth using & & & \\
\hline On time delivery & \multirow[t]{2}{*}{ Value } & \multirow[t]{2}{*}{ B4 } & \multirow[t]{2}{*}{ [11] } \\
\hline Experience & & & \\
\hline $\begin{array}{l}\text { Information coor- } \\
\text { dination }\end{array}$ & \multirow[t]{2}{*}{$\begin{array}{l}\text { Communicati } \\
\text { on system }\end{array}$} & \multirow[t]{2}{*}{ B5 } & \multirow[t]{2}{*}{ [12] } \\
\hline Operation control & & & \\
\hline
\end{tabular}

\subsubsection{Determining the Relative Importance of} "WHATs".

The weighting is done by filling out a questionnaire by each stakeholder / respondent (R). Respondents who filled out the questionnaire included the Procurement Department, the Logistics Service Department, and the President Director of KAL Inc.

Filling out the questionnaire is done by filling in the importance level column using linguistic terms Very
High (VH), High (H), Medium (M), Low (L), Very Low (VL) [3], [13]. The results of the questionnaire with linguistic terms are then converted into a triangular fuzzy number $I R_{i}=\left(I R_{i l}, I R_{i m}, I R_{i u}\right)$. Table 2 is the linguistic scale used in this study.

Table 2. Variables and Linguistic Scales used

\begin{tabular}{|l|c|c|c|}
\hline \multirow{2}{*}{$\begin{array}{c}\text { Variable Lin- } \\
\text { guistic }\end{array}$} & \multicolumn{3}{|c|}{ Triangular Fuzzy Number } \\
\cline { 2 - 4 } & lower $(\mathrm{I})$ & $\begin{array}{c}\text { Middle } \\
(\mathrm{m})\end{array}$ & $\begin{array}{c}\text { Upper } \\
(\mathrm{u})\end{array}$ \\
\hline Very Low & 0 & 1 & 2 \\
\hline Low & 2 & 3 & 4 \\
\hline Medium & 4 & 5 & 6 \\
\hline High & 6 & 7 & 8 \\
\hline Very High & 8 & 9 & 10 \\
\hline
\end{tabular}

Table 3. Importance Rating of WHATs of Combined Respondents

\begin{tabular}{|c|c|c|c|}
\hline \multirow{2}{*}{ WHATs } & \multicolumn{3}{|c|}{ Importance Rating of WHATs } \\
\cline { 2 - 4 } & $\mathrm{I}$ & $\mathrm{m}$ & $\mathrm{u}$ \\
\hline $\mathrm{A} 1$ & 8 & 9 & 10 \\
\hline $\mathrm{A} 2$ & 7.2 & 8.2 & 9.2 \\
\hline A3 & 7.6 & 8.6 & 9.6 \\
\hline A4 & 7.8 & 8.8 & 9.8 \\
\hline A5 & 6.8 & 7.8 & 8.8 \\
\hline A6 & 7.8 & 8.8 & 9.8 \\
\hline A7 & 6.2 & 7.2 & 8.2 \\
\hline A8 & 7.2 & 8.2 & 9.2 \\
\hline A9 & 7 & 8 & 9 \\
\hline
\end{tabular}

Table 1. "WHAT" - "HOW', Correlation Scores

\begin{tabular}{|c|c|c|c|c|c|c|c|c|c|c|c|c|c|c|c|}
\hline HOWs & \multicolumn{3}{|c|}{ B1 } & \multicolumn{3}{|c|}{ B2 } & \multicolumn{3}{|c|}{ B3 } & \multicolumn{3}{|c|}{ B4 } & \multicolumn{3}{|c|}{ B5 } \\
\hline WHATs & 1 & $\mathrm{~m}$ & $U$ & 1 & $\mathrm{~m}$ & $U$ & 1 & $\mathrm{~m}$ & $U$ & 1 & $\mathrm{~m}$ & $U$ & 1 & $\mathrm{~m}$ & $U$ \\
\hline $\mathrm{A} 1$ & 7.8 & 8.8 & 9.8 & 6.2 & 7.2 & 8.2 & 6 & 7 & 8 & 5.6 & 6.6 & 7.6 & 6.4 & 7.4 & 8.4 \\
\hline $\mathrm{A} 2$ & 7 & 8 & 9 & 5.8 & 6.8 & 7.8 & 5.6 & 6.6 & 7.6 & 5.4 & 6.4 & 7.4 & 6.2 & 7.2 & 8.2 \\
\hline A3 & 6.4 & 7.4 & 8.4 & 7.4 & 8.4 & 9.4 & 7.2 & 8.2 & 9.2 & 6.4 & 7.4 & 8.4 & 5.6 & 6.6 & 7.6 \\
\hline A4 & 6.8 & 7.8 & 8.8 & 6.6 & 7.6 & 8.6 & 6.8 & 7.8 & 8.8 & 7.2 & 8.2 & 9.2 & 5.8 & 6.8 & 7.8 \\
\hline A5 & 0.2 & 7.2 & 8.2 & 6.2 & 7.2 & 8.2 & 7.2 & 8,2 & 9.2 & 6.4 & 7.4 & 8.4 & 5.6 & 6.6 & 7.6 \\
\hline A6 & 7.8 & 8.8 & 9.8 & 6 & 7 & 8 & 7 & 8 & 9 & 7.4 & 8.4 & 9.4 & 7.4 & 8.4 & 9.4 \\
\hline A7 & 5.6 & 6.6 & 7.6 & 5.8 & 6.8 & 7.8 & 6 & 7 & 8 & 6 & 7 & 8 & 6.2 & 7.2 & 8.2 \\
\hline A8 & 6.4 & 7.4 & 8.4 & 4.8 & 5.8 & 6.8 & 5.6 & 6.6 & 7.6 & 6 & 7 & 8 & 7.8 & 8.8 & 9.8 \\
\hline A9 & 6.8 & 7.8 & 8.8 & 4.8 & 5.8 & 6.8 & 6.2 & 7.2 & 8.2 & 6.4 & 7.4 & 8.4 & 7.6 & 8.6 & 9.6 \\
\hline
\end{tabular}


The table 4 is the linguistic variable and triangular fuzzy number used in this paper. $\mathrm{VL} \rightarrow(0,1,2) ; \mathrm{L} \rightarrow(2$, $3,4) ; \mathrm{M} \rightarrow(4,5,6) ; \mathrm{H} \rightarrow(6,7,8) ; \mathrm{VH} \rightarrow(8,9,10)$. In this study, the level of importance of WHATs given by the respondents was collected and then averaged with the following equation: IMPORTANCE RATING ${ }_{W H A T s}=$ $\left\{\mathrm{IR}_{\mathrm{i}}\right.$, where $\left.\mathrm{i}=1, \ldots, \mathrm{k}\right\}$;

$$
I R i=\frac{1}{n} x\left(I R i_{1}+I R i_{2}+I R i_{3}+\ldots .+I R i_{n}\right)
$$

Where

$\mathrm{k}=$ Number of WHATs (9 WHATs)

$\mathrm{n} \quad=$ Number of Resopondens (10 Respondens)

The following is the result of filling out the WHATs importance level questionnaire with the combined average of all respondents which has been quantified into a triangular fuzzy number:

\subsection{Determining the Correlation Score of "WHATs" - "HOWs"}

Respondents were asked to fill in using one of five linguistic variables on the correlation between WHATs and HOWs. Determining this score also uses a triangular fuzzy number to quantify the variables that have been filled in by each respondent $\mathrm{CR}_{\mathrm{ij}}=\left(\mathrm{CR}_{\mathrm{ijl}}, \mathrm{CR}_{\mathrm{ijm}}, \mathrm{CR}_{\mathrm{iju}}\right)$. The fuzzy numbers obtained are then added up using the following equation:

Table 4. Weight of HOWs

\begin{tabular}{|c|c|c|c|c|c|c|c|c|c|c|c|c|}
\hline HOWs & \multicolumn{3}{|c|}{$\begin{array}{l}\text { Important Rat- } \\
\text { ing fo WHATs }\end{array}$} & \multicolumn{3}{|c|}{ B1 } & \multicolumn{3}{|c|}{ B2 } & \multicolumn{3}{c|}{ B3 } \\
\hline WHATs & 1 & $\mathrm{~m}$ & $\mathrm{U}$ & 1 & $\mathrm{~m}$ & $\mathrm{U}$ & 1 & $\mathrm{~m}$ & $\mathrm{U}$ & 1 & $\mathrm{~m}$ & $\mathrm{U}$ \\
\hline $\mathrm{A} 1$ & 8 & 9 & 10 & 7.8 & 8.8 & 9.8 & 6.2 & 7.2 & 8.2 & 6 & 7 & 8 \\
\hline A2 & 7.2 & 8.2 & 9.2 & 7 & 8 & 9 & 5.8 & 6.8 & 7.8 & 5.6 & 6.6 & 7.6 \\
\hline A3 & 7.6 & 8.6 & 9.6 & 6.4 & 7.4 & 8.4 & 7.4 & 8.4 & 9.4 & 7.2 & 8.2 & 9.2 \\
\hline A4 & 7.8 & 8.8. & 9.8 & 6.8 & 7.8 & 8.8 & 6.6. & 7.6 & 8.6 & 6.8 & 7.8 & 8.8 \\
\hline A5 & 6.8 & 7.8 & 8.8 & 6.2 & 7.2 & 8.2 & 6.2 & 7.2 & 8.2 & 7.2 & 8.2 & 9.2 \\
\hline A6 & 7.8 & 8.8 & 9.8 & 7.8 & 8.8. & 9.8 & 6 & 7 & 8 & 7 & 8 & 9 \\
\hline A7 & 6.2 & 7.2 & 8.2 & 5.6 & 6.6 & 7.6 & 5.8 & 6.8 & 7.8 & 6 & 7 & 8 \\
\hline A8 & 7.2 & 8.2 & 9.2 & 6.4 & 7.4 & 8.4 & 4.8 & 5.8 & 6.8 & 5.6 & 6.6 & 7.6 \\
\hline A9 & 7 & 8 & 9 & 6.8 & 7.8 & 8.8 & 4.8 & 5.8 & 6.8 & 6.2 & 7.2 & 8.2 \\
\hline \multicolumn{3}{|c|}{ Weight of (HOWs) } & 49.54 & 64.59 & 81.63 & 43.57 & 57.82 & 74.06 & 46.73 & 61.42 & 78.11 \\
\hline
\end{tabular}

Table 5.continued....

\begin{tabular}{|c|c|c|c|c|c|c|c|c|c|}
\hline HOWs & \multicolumn{2}{|c|}{$\begin{array}{l}\text { Important Rat- } \\
\text { ing of WHATs }\end{array}$} & \multicolumn{3}{|c|}{ B4 } & \multicolumn{3}{c|}{ B5 } \\
\hline WHATs & 1 & $\mathrm{~m}$ & $\mathrm{U}$ & 1 & $\mathrm{~m}$ & $\mathrm{U}$ & 1 & $\mathrm{~m}$ & $\mathrm{U}$ \\
\hline A1 & 8 & 9 & 10 & 5.6 & 6.6. & 7.6 & 6.4 & 7.4 & 8.4 \\
\hline A2 & 7.2 & 8.2 & 9.2 & 5.4 & 6.4 & 7.4 & 6.2 & 7.2 & 8.2 \\
\hline A3 & 7.6 & 8.6 & 9.6 & 6.4 & 7.4 & 8.4 & 5.6 & 6.6 & 7.6 \\
\hline A4 & 7.8 & 8.8. & 9.8 & 7.2 & 8.2 & 9.2 & 5.8 & 6.8 & 7.8 \\
\hline A5 & 6.8 & 7.8 & 8.8 & 6.4 & 7.4 & 8.4 & 5.6 & 6.6 & 7.6 \\
\hline A6 & 7.8 & 8.8. & 9.8 & 7.4 & 8.4 & 9.4 & 7.4 & 8.4 & 9.4 \\
\hline A7 & 6.2 & 7.2 & 8.2 & 6 & 7 & 8 & 6.2 & 7.2 & 8.2 \\
\hline A8 & 7.2 & 8.2 & 9.2 & 6 & 7 & 8 & 7.8 & 8.8. & 9.8 \\
\hline A9 & 7 & 8 & 9 & 6.4 & 7.4 & 8.4 & 7.6 & 8.6 & 9.6 \\
\hline \multicolumn{3}{|c|}{ Weight of (HOWs) } & 46.10 & 60.70 & 77.30 & 47.47 & 62.27 & 79.07 \\
\hline
\end{tabular}


CORELATION RATING $=\left\{\mathrm{CR}_{\mathrm{ij}}\right.$,

where $i=1, \ldots, k \& j=1, \ldots, m\}$,

$$
\mathrm{CR}_{\mathrm{ij}}=\frac{1}{n} \mathrm{x}\left(\mathrm{CR}_{\mathrm{ij} 1}+\mathrm{CR}_{\mathrm{ij} 2}+\mathrm{CR}_{\mathrm{ij} 3}+\ldots .++\mathrm{CR}_{\mathrm{ijn}}\right)
$$

Where

$\mathrm{k}=$ Number of WHATs (9)

$\mathrm{m}=$ Number of HOWs (5)

$\mathrm{n}$ = Number of Resopondens (10)

The following is a correlation table "WHATs " - " HOWs " from the results of filling out the questionnaire that has been quantified and combined by all respondents.

\subsection{Determining the Weight of the " $\mathrm{HOWs}$ "'}

The next step is to determine the weight of each HOW by calculating the following equation:

WEIGHT $_{\text {HOWs }}=\left\{\mathrm{W}_{\mathrm{j}}\right.$, where $\left.\mathrm{j}=1, \ldots, \mathrm{m}\right\}$

$$
\mathrm{WH}_{\mathrm{j}}=\frac{1}{n} \times\left[\left(\mathrm{IR}_{\mathrm{i}} \times \mathrm{CR}_{\mathrm{ij}}+\ldots .+\mathrm{IR}_{\mathrm{k}} \times C \mathrm{R}_{\mathrm{ik}}\right)\right]
$$

Where

$\mathrm{k}=$ Number of WHATs (9)

$\mathrm{m}=$ Number of HOWs (5)

Determination of this weight also uses a triangular fuzzy number $\mathrm{WH}_{\mathrm{j}}=\left(\mathrm{WH}_{\mathrm{jl}}, \mathrm{WH}_{\mathrm{jm}}, \mathrm{WH}_{\mathrm{ju}}\right)$. Table 5 shows the results of calculating the How's weight.

\subsubsection{Create a Correlation Matrix between "HOWs"}

At this stage, a correlation matrix will be made from each HOWs. Making this correlation matrix is done by brainstorming with decision makers. The following is the result of determining the correlation matrix that has been made.

Matrix creation is done by entering symbols into each column. If it has a strong positive relationship, it is given a solid circle symbol (O), if it has a positive relationship, it is given a circle symbol (O), if it has a negative relationship, it is given a cross symbol (x), and if it has a negative strong relationship, it is given a star symbol (*) [14].

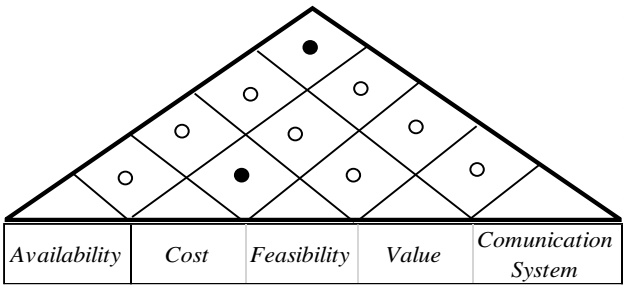

Figure 1. Correlation Matrix between "HOWs"

After all the steps have been done, the overall HOQ image will be obtained from each element that has been created. Fig. 3 is a completed HOQ that has been made.

\subsubsection{Determine the Impact of Each Trailer Vendor on the Attributes Considered (HOWs).}

After obtaining the weighting of each HOWs, the next step is to assess each available trailer vendor based on predetermined criteria (HOWs). Determination of the assessment of each trailer vendor also uses a triangular fuzzy number $\mathrm{VR}_{\mathrm{hj}}=\left(\mathrm{VR}_{\mathrm{hjl}}, \mathrm{VR}_{\mathrm{hjm}}, \mathrm{VR}_{\mathrm{hju}}\right)$. Calculations are carried out with the following equation:

VENDOR RATING $=\left\{\mathrm{VR}_{\mathrm{hj}}\right.$, where $\mathrm{h}=1, \ldots, \mathrm{p}$ and $\mathrm{j}$ $=1, \ldots, \mathrm{m})$

$$
\mathrm{VR}_{\mathrm{hj}}=\frac{\mathbf{1}}{\boldsymbol{n}} \times\left(\mathrm{VR}_{\mathrm{hj} 1}+\mathrm{VR}_{\mathrm{hj} 2}+\ldots+\mathrm{VR}_{\mathrm{hjn}}\right)
$$

Where

$\mathrm{m} \quad=$ Number of HOWs (5)

$\mathrm{p} \quad=$ Number of Trailer Vendor (7)

The following are the results of respondents' assessment of available trailer vendors based on predetermined cri-

\begin{tabular}{|c|c|c|c|c|c|c|c|c|c|c|c|c|c|c|c|}
\hline \multirow{2}{*}{ Vendor } & \multicolumn{3}{|c|}{ B1 } & \multicolumn{3}{|c|}{ B2 } & \multicolumn{3}{|c|}{ B3 } & \multicolumn{3}{|c|}{ B4 } & \multicolumn{3}{|c|}{ B5 } \\
\hline & 1 & $\mathrm{~m}$ & $U$ & 1 & $\mathrm{~m}$ & $U$ & 1 & $\mathrm{~m}$ & U & 1 & $\mathrm{~m}$ & U & 1 & $\mathrm{~m}$ & U \\
\hline LAA Inc. & 6.6 & 7.6 & 8.6 & 5.8 & 6.8 & 7.8 & 4.8 & 5.8 & 6.8 & 5.4 & 6.4 & 7.4 & 6 & 7 & 8 \\
\hline ISLC Inc. & 5 & 6 & 7 & 5.2 & 6.2 & 7.2 & 5.6 & 6.6 & 7.6 & 4.8 & 5.8 & 6.8 & 5.4 & 6.4 & 7.4 \\
\hline PSJ Inc. & 4.8 & 5.8 & 6.8 & 5.4 & 6.4 & 7.4 & 3.8 & 4.8 & 5.8 & 4.8 & 5.8 & 6.8 & 4.8 & 5.8 & 6.8 \\
\hline JS Inc. & 7 & 8 & 9 & 5.6 & 6.6 & 7.6 & 5.6 & 6.6 & 7.6 & 5.6 & 6.6 & 7.6 & 7 & 8 & 9 \\
\hline KSK Inc. & 5 & 6 & 7 & 5.6 & 6.6 & 7.6 & 5.4 & 6.4 & 7.4 & 5.2 & 6.2 & 7.2 & 5.2 & 6.2 & 7.2 \\
\hline SBW Inc. & 4.6 & 5.6 & 6.6 & 5.4 & 6.4 & 7.4 & 5.2 & 6.2 & 7.2 & 5 & 6 & 7 & 5.4 & 6.4 & 7.4 \\
\hline GPG Inc & 7.2 & 8.2 & 9.2 & 6.4 & 7.4 & 8.4 & 6.2 & 7.2 & 8.2 & 5.8 & 6.8 & 7.8 & 6.8 & 7.8 & 8.8 \\
\hline
\end{tabular}
teria.

Table 6. Assessment of Vendors Based on HOWs 

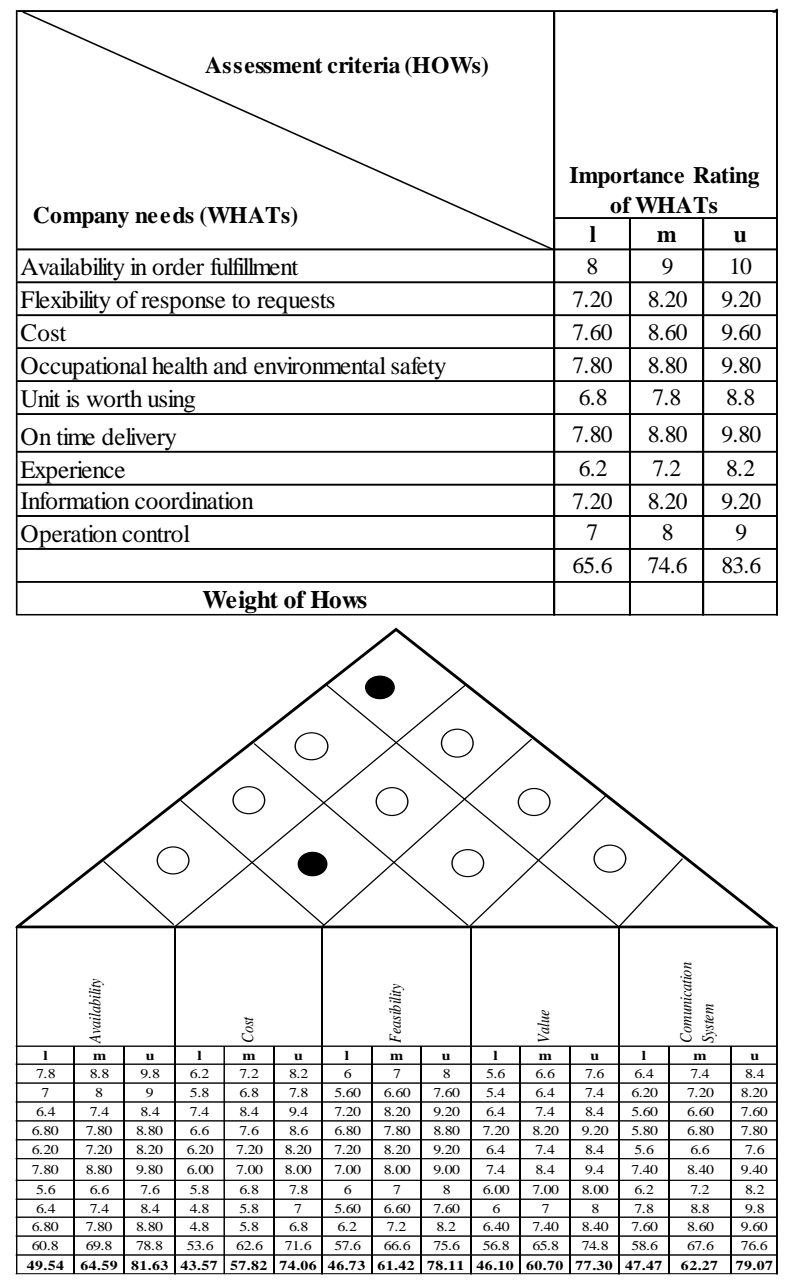

Figure 2. The Completed HOQ

\subsubsection{Compile the Final Ranking based on the FSI (Fuzzy Suitability Index).}

In the final stage of the fuzzy-QFD method, the score is determined based on the calculation of fuzzy suitability index (FSI). The FSIh index is a triangular fuzzy number derived from a previously calculated aggregate score, multiplied by the weight for each scoring criteria. FSI calculations use the following equations:

FUZZY SUITABILITY INDEX $=\left\{\right.$ FSI $_{\mathrm{h}}$, where $\mathrm{h}=1$, $\ldots, p\}$,

$\mathrm{FSI}_{\mathrm{h}}=\frac{1}{\boldsymbol{m}} \times\left[\left(\mathrm{VR}_{\mathrm{h} 1} \times \mathrm{W}_{1}\right) \times\left(\mathrm{VR}_{\mathrm{hm}} \times \mathrm{W}_{\mathrm{m}}\right)\right]$

Where

$\mathrm{m} \quad=$ Number of HOWs (5)

$\mathrm{p} \quad=$ Number of Trailer Vendor (7)
The FSI vector contains the FSI index for each trailer vendor in the form of a triangular fuzzy number $\mathrm{FSI}_{\mathrm{h}}=$ (FSI $\left.\mathrm{Fl}_{\mathrm{h}}, \mathrm{FSI}_{\mathrm{hm}}, \mathrm{FSI}_{\mathrm{hu}}\right)$. Calculation of FSI components using the following equations:

$$
\begin{aligned}
\mathbf{F S I}_{h l} & =\frac{1}{m} \sum_{j=1}^{m} S R_{h j l} \cdot W_{J l} \\
\text { FSI }_{h m} & =\frac{1}{m} \sum_{j=1}^{m} S R_{h j m} \cdot W_{J m} \\
\text { FSI }_{h u} & =\frac{1}{m} \sum_{j=1}^{m} S R_{h j u} \cdot W_{J u}
\end{aligned}
$$

The FSI calculation results are then used to determine the score and match of each trailer vendor. Trailer vendor score calculation is done by using the following equation: $\mathrm{SCORE}=\left\{\mathrm{S}_{\mathrm{h}}\right.$, where $\left.\mathrm{h}=1, \ldots, \mathrm{p}\right\}$

$$
\mathrm{S}_{\mathrm{h}}=\frac{F N_{l}+2 \cdot F N_{m}+F N_{u}}{4}
$$

The following are the results of the FSI calculation that has been done.

Table 6. FSI of Trailer Vendor

\begin{tabular}{|c|l|c|c|c|}
\hline \multirow{2}{*}{ No } & \multirow{2}{*}{$\begin{array}{c}\text { Trailer } \\
\text { Vendor }\end{array}$} & \multicolumn{3}{|c|}{ FSI } \\
\cline { 3 - 5 } & V & $\mathrm{m}$ & $\mathrm{u}$ \\
\hline 1 & LAA Inc. & 267.56 & 412.93 & 603.09 \\
\hline 2 & ISLC Inc. & 242.72 & 380.39 & 561.81 \\
\hline 3 & PSJ Inc. & 219.96 & 350.54 & 523.90 \\
\hline 4 & JS Inc. & 288.59 & 440.49 & 638.06 \\
\hline 5 & KSK Inc. & 246.13 & 384.93 & 567.63 \\
\hline 6 & SBW Inc. & 238.61 & 375.05 & 555.09 \\
\hline 7 & GPG Inc. & 303.10 & 459.63 & 662.48 \\
\hline
\end{tabular}

Table 7. Trailer Vendor Scores and Rankings

\begin{tabular}{|l|l|l|c|}
\hline No & Vendor & Score & Ranking \\
\hline 1 & LAA Inc. & 424.12 & 3 \\
\hline 2 & ISLC Inc. & 391.33 & 5 \\
\hline 3 & PSJ Inc. & 361.24 & 7 \\
\hline 4 & JS Inc. & 451.91 & 2 \\
\hline 5 & KSK Inc. & 395.90 & 4 \\
\hline 6 & SBW Inc. & 385.95 & 6 \\
\hline 7 & GPG Inc. & 471.21 & 1 \\
\hline
\end{tabular}

\subsection{Goal Programming}

In the completion of Goal Programming will be calculated a case study of one domestic delivery project Slab Steel products from KP Inc. Area to BEKASI Area. The following secondary data is obtained from company data for one Slab Steel delivery project. 
The table above is trailer vendor data obtained from data in the procurement division. In the table are known cost and capacity of each trailer vendor for one Slab Steel delivery project. Trailer vendor rates and capacity always change depending on the project. In the table is also known the score value of each trailer vendor obtained from the previous fuzzy-QFD calculation.

The number of products that must be sent using vendors is as much as 13,000 Tons, with the company's budget of IDR 910,000,000. The following are the stages of completion of Goal Programming.

Table 8. Project Slab Steel Delivery Trailer Vendor Data

\begin{tabular}{|c|l|c|c|c|}
\hline No & Vendor & $\begin{array}{l}\text { Cost/tons } \\
\text { (IDR) }\end{array}$ & $\begin{array}{c}\text { Capacity } \\
\text { (tons) }\end{array}$ & Score \\
\hline 1 & LAA Inc. & 6800 & 2000 & 424.12 \\
\hline 2 & ISLC Inc. & 6800 & 2000 & 391.33 \\
\hline 3 & PSJ Inc. & 6800 & 2000 & 361.24 \\
\hline 4 & JS Inc. & 6800 & 4000 & 451.91 \\
\hline 5 & KSK Inc. & 6800 & 2000 & 395.9 \\
\hline 6 & SBW Inc. & 6800 & 1000 & 385.95 \\
\hline 7 & GPG Inc. & 6800 & 4000 & 471.21 \\
\hline
\end{tabular}

\subsubsection{Data Formulation}

1. Linier programming formulation

The following is a linear programming formulation from the research conducted, namely the determination of decision variables, objective functions, and constraints.

a. Decision Variable

The decision variable of this study is the determination and allocation of trailer vendors for the delivery of Slab Steel products $\left(\mathrm{X}_{\mathrm{i}}\right)$.

Where

$\mathrm{X}=$ Slab Steel sent by Trailer vendor $\mathrm{i}$.

$\mathrm{i}=$ Trailer Vendor $(\mathrm{i}=1,2, \ldots, \mathrm{n})$.

b. Objective Function

In this study there are several goals that want to be achieved, namely:

Goal 1 : Minimization Total Cost

Minimizing the cost of shipping Slab Steel is aimed at obtaining an economical model, so that the costs incurred by the company for Slab Steel delivery can be minimal.

Where:

$$
\operatorname{Min}\left(\mathrm{Z}_{1}\right)=\sum_{\boldsymbol{i}=\mathbf{1}}^{\boldsymbol{n}} \boldsymbol{C}_{\boldsymbol{i}} * \boldsymbol{X}_{\boldsymbol{i}}
$$

$\mathrm{X}_{\mathrm{i}} \quad=$ Slab Steel sent by Trailer Vendor $\mathrm{i}$.

$\mathrm{C}_{\mathrm{i}} \quad=$ Trailer Vendor Shipping Costs /Tons

$\mathrm{i}=$ Trailer Vendor Trailer $(\mathrm{i}=1,2, \ldots, \mathrm{n})$.
Goal 2: Maximization Total Score

The total score processed is the result of the previous Fuzzy-QFD calculation.

$\operatorname{Max}\left(\mathrm{Z}_{2}\right)=\sum_{i=\mathbf{1}}^{n} \boldsymbol{S}_{\boldsymbol{i}} * \boldsymbol{X}_{\boldsymbol{i}}$

$\mathrm{X}_{\mathrm{i}} \quad=$ Slab Steel sent by Trailer Vendor $\mathrm{i}$.

$\mathrm{S}_{\mathrm{i}} \quad=$ Trailer Vendor Score

$\mathrm{i} \quad=$ Trailer Vendor Trailer $(\mathrm{i}=1,2, \ldots, \mathrm{n})$.

c. Constrain

The following are the constraints contained in the model created.

Constraint 1: Project Slab Steel Delivery Number Requirement

$\sum_{i=1}^{n} X_{i}=13,000$ Tons

$\mathrm{X}_{\mathrm{i}} \quad=$ Slab Steel sent by Trailer Vendor $\mathrm{i}$.

$\mathrm{i}=\quad=$ Trailer Vendor Trailer $(\mathrm{i}=1,2, \ldots, \mathrm{n})$.

Constraint 2: company's budget

$\sum_{i=1}^{n} C_{i} * X_{i} \leq I D R 897,000,000$

Where

$\mathrm{X}_{\mathrm{i}} \quad=$ Slab Steel sent by Trailer Vendor $\mathrm{i}$.

$\mathrm{C}_{\mathrm{i}} \quad=$ Trailer Vendor Shipping Costs

/Tons.

$\mathrm{i}=$ Trailer Vendor Trailer $(\mathrm{i}=1,2, \ldots, \mathrm{n})$.

Constraint 3: Vendor Capacity

$\sum_{i=1}^{n} X_{i} \leq K_{i}$

Where

$\mathrm{X}_{\mathrm{i}} \quad=$ Slab Steel sent by Trailer Vendor $\mathrm{i}$.

$\mathrm{K}_{\mathrm{i}} \quad=$ Trailer Vendor Capacity

i $\quad=$ Trailer Vendor Trailer $(\mathrm{i}=1,2, \ldots, \mathrm{n})$.

2. Goal Programming Formulation

Once a linear programming model has been created, the next step is to turn that model into a Goal Programming model. In the goal programming method there is a deviation variable that has a function in accommodating deviations or deviations that will occur in the value of the left field of a constrain equation against the value of its right field [15].

Deviation variables that need to be added to the goal programming model are as follows:

$d_{j}^{-}=$deviation value below

$d_{j}^{+}=$deviation value above

By using the addition of variable deviation, the additional limitations derived from the Linear Programming destination function are changed to the following:

- Minimization Total Costs 


$$
\begin{gathered}
C_{(1)} * X_{(1)}+C_{(2)} * X_{(2)}+\ldots+C_{(7)} * X_{(7)}+ \\
d_{1}^{-}-d_{1}^{+}=0
\end{gathered}
$$

Because the goal is to minimize costs, then positive deviations, the total cost of using trailer vendors is attempted zero [16].

- Maximization Total Score

$$
\begin{gathered}
S_{(1)} * X_{(1)}+S_{(2)} * X_{(2)}+\ldots+S_{(7)} * \\
X_{(7)}+d_{2}^{-}-d_{2}^{+}=6,125,730
\end{gathered}
$$

Because the goal is to maximize the total score, then negative deviations (short of the total score of the target) are attempted zero [16]. 6,125,730 is the vendor's highest total score (471.21) multiplied by the number of Slab Steel that needs to be sent (13,000 tons), in this case being targeted to maximize the score value.

The new goal function in Goal programming consists of deviation variables. Where there is a provision in Goal programming in determining a new goal function, the provision is [16]:

1. If the initial formula of the goal is maximization, then the new goal function is to minimize $\mathrm{dj}^{-}$.

2. If the initial formula of the goal is minimization, then the new goal function is to minimize $\mathrm{dj}^{+}$.

Based on these provisions, the objectives of Goal Programming shall be as follows:

Goal 1:

Goal 2:

$$
\operatorname{Min} \mathrm{Z}=\sum \boldsymbol{d}_{\mathbf{1}}^{+}
$$

$$
\text { Min } \mathrm{Z}=\sum \boldsymbol{d}_{\mathbf{2}}^{-}
$$

So that the purpose function becomes as follows:

$$
\text { Min } \mathrm{Z} \text { deviation }=\boldsymbol{d}_{\mathbf{1}}^{+}+\boldsymbol{d}_{\mathbf{2}}^{-}
$$

3. Formulation of Goal Programming Constraints The following are the Goal Programming constraints of the model:

- $\quad$ Project Slab Steel Delivery Number Requirement

Where

$$
\sum_{i=1}^{n} X_{i}=13,000 \text { Tons }
$$

$\mathrm{X}_{\mathrm{i}} \quad=$ Slab Steel sent by Trailer Vendor $\mathrm{i}$.

- company's budget

Where

$$
\sum_{i=1}^{n} C_{i} * X_{i} \leq I D R 897,000,000
$$

$\mathrm{X}_{\mathrm{i}} \quad=$ Slab Steel sent by Trailer Vendor $\mathrm{i}$.

$\mathrm{Ci}=$ Trailer Vendor Shipping Costs /Tons.

$\mathrm{i}=$ Trailer Vendor Trailer $(\mathrm{i}=1,2, \ldots, \mathrm{n})$.
- Trailer Vendor Capacity

$$
\sum_{i=1}^{n} X_{i} \leq K_{i}
$$

Where

$\mathrm{Xi}=$ Slab Steel sent by Trailer Vendor i.

$\mathrm{Ki}=$ Trailer Vendor Capacity

$\mathrm{i} \quad=$ Trailer Vendor Trailer $(\mathrm{i}=1,2, \ldots, \mathrm{n})$.

\subsubsection{Result Goal Programming}

Completion is done with the help of LINGO software. The goal programming model that has been created is incorporated into lingo software and then run the simulation model. Table 10 shows the results of the delivery allocation obtained after running the simulation model that has been created with the LINGO software.

From the table above it is known that the allocation of shipments by LAA Inc. of 2000 tons, ISLC Inc.of 2000 tons, JS Inc. of 4000 tons, KSK Inc. of 2000 tons and GPG Inc. of 4000 tons. So the total of the whole is 13000 tons. These results are in accordance with the data constraints of the company, which is not exceeding the total capacity of each vendor. Model validation is done by performing sensitivity analysis when creating models in Lingo. Sensitivity analysis provides an idea of the extent to which a decision will be strong enough to deal with changes in factors or parameters that affect [17].

Table 11 shows the result of goal values obtained after running the simulation model.

From the table 11, it is known that the total cost that the company needs to pay for a case study of the slab delivery project is IDR $884,000,000.00$ and a total score of 572,3850. These results are in accordance with the company's constraint, which should not exceed the company's budget.

Table 9. Recapitulation of Slab Steel Delivery Allocation (Tons)

\begin{tabular}{|c|l|c|}
\hline No & Trailer Vendor & $\begin{array}{c}\text { Slab Steel Delivery } \\
\text { Allocation } \\
\text { (Tons) }\end{array}$ \\
\hline 1 & LAA Inc. & 2000 \\
\hline 2 & ISLC Inc. & 2000 \\
\hline 3 & PSJ Inc. & 0 \\
\hline 4 & JS Inc. & 4000 \\
\hline 5 & KSK Inc. & 2000 \\
\hline 6 & SBW Inc. & 0 \\
\hline 7 & GPG Inc. & 4000 \\
\hline
\end{tabular}


Table 10. Goal Result

\begin{tabular}{|c|c|c|}
\hline No & Goal & Result \\
\hline 1 & Cost & IDR $884,000,000$ \\
\hline 2 & Score & 572,3850 \\
\hline
\end{tabular}

Table 11. Recapitulation of the Simulation Calculation Results for Deviation Goal Values

\begin{tabular}{|c|c|c|}
\hline No & Deviation & Result \\
\hline 1 & D1 Cost Minimization & $884,000,000$ \\
\hline 2 & D2 Score Maximization & 401,880 \\
\hline
\end{tabular}

Deviation variable in the model serves to accommodate deviations from the expected target. Table 12 shows the recapitulation of the simulation calculation results for deviation goal values.

In the table above, it is known that the value of the deviation of the cost minimization is $884,000,000$ and the deviation of the maximum score is 401,880 . These results are deviations from the target model that is made, namely the total target cost is attempted to be 0 , and the total target score is $6,125,730$.

\section{CONCLUSION}

The following are the conclusions of this study:

1. The criteria used in the selection of trailer vendors include availability, cost, feasibility, value, and communication system.

2. Based on the calculations, the results obtained are GPG Inc. is ranked 1 with a score of 471.21 , JS Inc. is ranked 2 nd with a score of 451.91 , LAA Inc. is ranked 3rd with a score of 424.12 , KSK Inc. is ranked 4 th with a score of 395.9 , ISLC Inc. is ranked 5th with a score of 391.33, SBW Inc. is ranked 6th with a score of 385.95 and PSJ Inc. is ranked 7th with a score of 361.24 .

3. The trailer vendor used in the Slab Steel delivery project at KAL Inc. is LAA Inc. of 2000 tons, ISLC Inc. of 1000 tons, JS Inc. of 4000 tons, KSK Inc. of 2000 tons and GPG Inc. 4000 tons.

\section{REFERENCES}

[1] Djamaris R A and Priyanto A 2011 Transporter Selection Strategy and Truck Type Using Linear Programming Model at PT. XYZ Business and Management Rev. 1 1-14

[2] Naafitamara S 2019 Application of the Analytic Hierarchy Process (AHP) Method in the Selection of
Trucking Vendors at PT. Surabaya Transmoda Jaya Calyptra 8 883-899

[3] Suhartini 2018 Fuzzy-Quality Function Deployment Approach in Supplier Selection J. of Mgt and Ind. Eng. 11 1-7

[4] Mulyati E and Widyapurna M P 2014 Priority Trucking Vendor Selection Model And Order Allocation For Delivery Project Account Perfetti Van Melle Indonesia (Case Study: Damco Indonesia Inc.) J@Ti Undip : Ind. Eng. J. 9 69-76

[5] Pandiya R, Wahyudin A, Nareswari S P 2016 Determination of Priority Scale for Interconnection Cost Regulations Using the Fuzzy QFD - TOPSIS Method J. Pekommas $177-88$

[6] Devani V and Basriati S 2015 Optimization of the Nutrient Content of Artificial Fish Feed by Using the Multi Objective (Goal) Programming Model J.of Sci., Tech. and Ind. 12 255-261

[7] Adriantantri E, Irawan J D, and Prasetio S 2016 Supplier Selection and Order Allocation Optimization System Ind. Inov. 6 41-44

[8] Bevilacqua M, Ciarapica F E, Giacchetta G 2006 A fuzzy-QFD approach to supplier selection J. of Purchasing and Supply Mgt 12 14-27

[9] Imaduddin M A and Riksakomara E 2017 Optimizing Supplier Selection and Coal Supply Allocation at PLTU Capacity $615 \mathrm{MW}$ by Using Analytical Hierarchy Process and Goal Programming Methods (Case Study PT.XYZ) J. Tek. ITS 6 2337-3520

[10] Titilias Y A, Linawati L, Parhusip H A 2018 Optimization of Plywood Production Planning PT. XXX Using Goal Programming Method J. MIPA $411-5$

[11] Ayağ Z, Samanlioglu F, Büyüközkan G 2013 A fuzzy QFD Approach To Determine Supply Chain Management Strategies in the Dairy Industry J.of Intelligent Mfg 24 1111-1122

[12] Pohan F 2017 Decision Support Integration Model for Vendor Selection Evaluation Using Fuzzy Analytical Network Process and TOPSIS Case Study PT Samudera Indonesia Ship Management J. Tek. $683-91$

[13] Wang L, Juan Y K, Wang J, Li K M, Ong C 2012 Fuzzy-QFD approach based decision support model for licensor selection Exp. Syst. with App 39 14841491

[14] Besterfield D H 2012 Total Quality Management (New Delhi : Dorling Kindersley)

[15] Ridwan A and Abadi A A 2020 Optimizing the Selection of Coal Raw Material Suppliers Using the Goal Programming Method (Case Study at PT. ABC) J. Ind. Serv. 6 20-26 
[16] Kabosu M Y and Kartiko K 2020 Analysis of Goal Programming (GP) in Optimizing Furniture Production Planning UD. Latanza J. of Ind. and Comput. Stat. 5 22-40

[17] Hasugian I A, Ingrid F, Wardana K 2020 Feasibility and Sensitivity Analysis: A Case Study of Mochi UKM, Medan Selayang District Eng. Main Bulletin J. 15 159-164 